ARTICLE

DOI: $10.1038 /$ ncomms11426

OPEN

\title{
Expression of a functional oxygen-labile nitrogenase component in the mitochondrial matrix of aerobically grown yeast
}

Gema López-Torrejón¹, Emilio Jiménez-Vicente', José María Buesa', Jose A. Hernandez², Hemant K. Verma ${ }^{1} \&$ Luis M. Rubio ${ }^{1}$

The extreme sensitivity of nitrogenase towards oxygen stands as a major barrier to engineer biological nitrogen fixation into cereal crops by direct nif gene transfer. Here, we use yeast as a model of eukaryotic cell and show that aerobically grown cells express active nitrogenase Fe protein when the $\mathrm{NifH}$ polypeptide is targeted to the mitochondrial matrix together with the NifM maturase. Co-expression of $\mathrm{NifH}$ and NifM with Nif-specific Fe-S cluster biosynthetic proteins NifU and NifS is not required for Fe protein activity, demonstrating $\mathrm{NifH}$ ability to incorporate endogenous mitochondrial Fe-S clusters. In contrast, expression of active Fe protein in the cytosol requires both anoxic growth conditions and co-expression of $\mathrm{NifH}$ and NifM with NifU and NifS. Our results show the convenience of using mitochondria to host nitrogenase components, thus providing instrumental technology for the grand challenge of engineering $\mathrm{N}_{2}$-fixing cereals.

\footnotetext{
${ }^{1}$ Centro de Biotecnología y Genómica de Plantas, Universidad Politécnica de Madrid, Pozuelo de Alarcón, Madrid 28223, Spain. ${ }^{2}$ Department of Biochemistry, Midwestern University, Glendale, Arizona 85308, USA. Correspondence and requests for materials should be addressed to L.M.R. (email: Im.rubio@upm.es).
} 
$\mathrm{P}$ roductivity of major crops is often limited by availability of fixed nitrogen sources such as $\mathrm{NH}_{3}$ and nitrate ${ }^{1}$. For the last 100 years, the addition of chemically synthesized nitrogen fertilizers has sustained crop productivity, but at significant environmental and economic costs ${ }^{2,3}$. An alternative sustainable solution to this problem is the incorporation of biological nitrogen fixation into cereal crops, for which transfer of bacterial nif genes into the plant is one possible strategy ${ }^{4-6}$.

Mo-nitrogenase is composed of two metalloproteins: the nifDK-encoded dinitrogenase component (also termed MoFe protein) that catalyses the reduction of $\mathrm{N}_{2}$ to $\mathrm{NH}_{3}$, and the nif $H$-encoded dinitrogenase reductase (also termed Fe protein) that is the obligate electron donor to the MoFe protein ${ }^{7}$. Additional gene products (minimally NifB, NifE and NifN) are required for the assembly of nitrogenase metal cofactors ${ }^{8,9}$. Both nitrogenase components, as well as most proteins required for the assembly of their metal clusters, are very sensitive to $\mathrm{O}_{2}$ (refs 10-12). The initial hypothesis of this work was that the mitochondrial matrix could provide a low $\mathrm{O}_{2}$ environment appropriate for the assembly and the activity of nitrogenase components similarly to the Azotobacter vinelandii respiratory protection $^{13}$. The $\mathrm{Fe}$ protein was chosen to obtain proof of concept because it is more sensitive to $\mathrm{O}_{2}$ than the MoFe protein $^{14}$ and because its maturation requirements are simpler ${ }^{5}$. In model diazotrophs Klebsiella pneumoniae and A. vinelandii, $\mathrm{NifH}$ polypeptides require NifM, NifS and NifU to render active Fe protein ${ }^{15,16}$. NifM is a putative peptidyl-prolyl isomerase ${ }^{17}$, whose exact role on NifH maturation has not been established. NifS is a cysteine desulfurase that provides $S$ for formation of $\mathrm{Fe}-\mathrm{S}$ clusters on the scaffolding protein NifU ${ }^{18,19}$, which in turn transfers $[4 \mathrm{Fe}-4 \mathrm{~S}]$ clusters to apo-NifH generating mature $\mathrm{Fe}$ protein $^{20}$. Here we show that targeting nitrogenase Fe protein to the mitochondrial matrix overcomes the $\mathrm{O}_{2}$ sensitivity problem, thus breaking through a major barrier to produce active nitrogenase within a eukaryotic cell.

\section{Results and Discussion}

Targeting of Nif proteins to yeast mitochondria. Saccharomyces cerevisiae was chosen as model eukaryotic cell for the following reasons: (i) the possibility to set different $\mathrm{O}_{2}$ levels during expression of Nif proteins, which allows troubleshooting negative $\mathrm{O}_{2}$ effects; (ii) its genetic amenability; and (iii) its mitochondrially located bacterial-like Fe-S cluster assembly machinery, which is the best understood among eukaryotes ${ }^{21}$. A. vinelandii nifH, nif $M$, nif $U$ and nifS genes were codon optimized for S. cerevisiae, cloned into expression vectors under the control of either GAL1 or GAL10 promoters, and introduced into S. cerevisiae W303-1a by transformation (Supplementary Table 1). GAL promoters were used as a way to induce nif gene expression and couple it to obligatory respiratory conditions (with galactose as the sole carbon source). For mitochondrial targeting, either sod2 (ref. 22) or su9 (ref. 23) leader sequences were fused to the $5^{\prime}$ end of each nif gene (Supplementary Fig. 1). To determine the effectiveness of mitochondrial leader sequences, we carried out intracellular localization experiments by using fluorescence confocal microscopy. For these experiments, NifH and NifS were tagged with yEGFP, while NifM and NifU were tagged with mKO. In galactose-induced cells, Nif proteins co-localized with MitoTracker dye indicating successful targeting to mitochondria (Fig. 1a). SDS-PAGE (polyacrylamide gel electrophoresis) immunoblot analysis of isolated mitochondria confirmed the presence of NifH, NifM, NifU and NifS in the mitochondrial matrix, as proteolytic degradation by Proteinase K treatment was only effective on detergent permeabilized mitochondria (Fig. 1b). In contrast, cytosolic versions of NifH, NifM, NifU and NifS
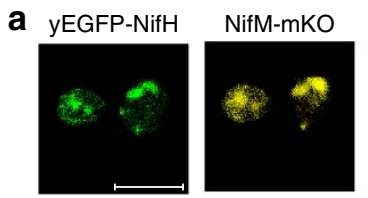

yEGFP-NifS

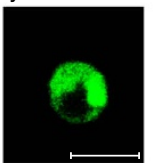

NifU-mKO
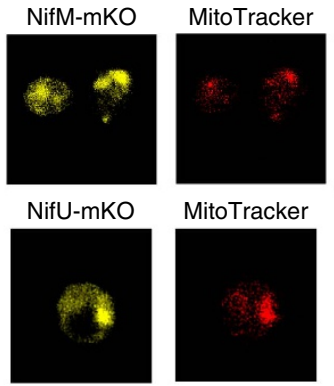

MitoTracker
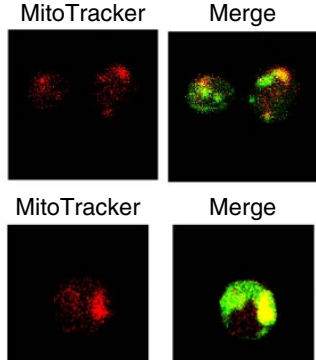

Merge
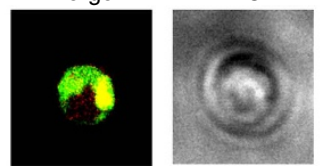

b
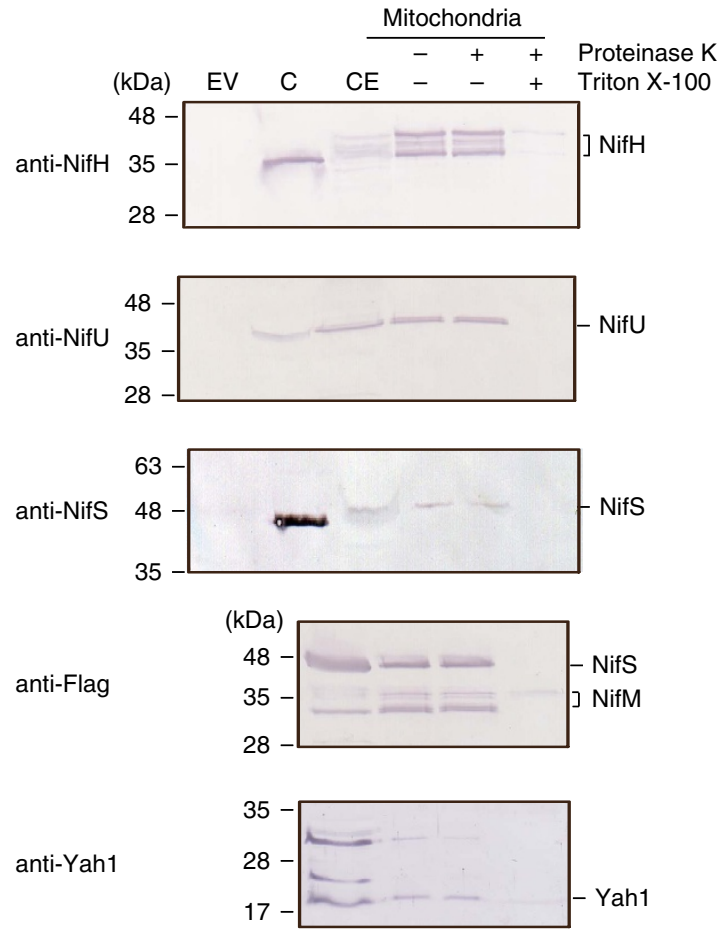

Figure 1 | Mitochondrial targeting of Nif proteins. (a) Confocal microscopy images of $S$. cerevisiae strains carrying synthetic sod2-yEGFPnifH and sod2-nifM-mKO (strain GF5) or sod2-yEGFP-nifS and sod2-mKO-nifU genes (strain GF7), which expression was induced by galactose in the growth medium. The mitochondria of galactose-induced cells were localized with MitoTracker Deep Red. Scale bar, $5 \mu \mathrm{m}$. (b) Immunoblot analysis of isolated mitochondria developed with antibodies against $\mathrm{NifH}$, NifU, NifS, Yah1 or FLAG (to detect NifS and NifM at the same time).

$\mathrm{EV}$ represents cell-free extracts from recombinant yeast carrying $\mathrm{pESC}-\mathrm{His}$ and pESC-Ura plasmids. CE represents cell-free extracts from recombinant yeast carrying $\mathrm{NifH}, \mathrm{NifM}, \mathrm{NifU}$ and NifS cloned into pESC-His and pESC-Ura plasmids (strain GF8). C represents control lanes with purified Nif proteins from $A$. vinelandii. Isolated mitochondria were treated with proteinase $\mathrm{K}$ either in the absence of detergent (for the removal of outer membrane proteins) or in the presence of Triton X-100 (to permeabilize the organelle).

(lacking mitochondrial leader sequences; Supplementary Fig. 1c) were not imported into the mitochondrial matrix.

Purification of active Fe protein from mitochondria. Strongly aerated $S$. cerevisiae cell cultures (1 litre air · per minute - per litre of culture) growing with galactose as carbon source and inducer of nif gene expression were used to produce recombinant Nif proteins. As cells grew respiring galactose, dissolved $\mathrm{O}_{2}$ remained below $0.25 \%$ (Supplementary Fig. 2). Importantly, under those growth conditions, $S$. cerevisiae cell-free extracts exhibited aconitase activity $(405 \pm 15 \mathrm{nmol}$ cis-aconitate $\cdot$ per minute per 
millilitre; mean \pm s.d.), which is known to be sensitive to reactive oxygen species ${ }^{24}$. In vivo half-life of the A. vinelandii $\mathrm{NifH}$ [4Fe-4S] cluster is $\sim 5 \mathrm{~min}$ under standard growth conditions, comparable to the $\mathrm{O}_{2}$-sensitive $[4 \mathrm{Fe}-4 \mathrm{~S}]$ cluster of $E$. coli aconitase $^{25}$. Mitochondrial his-tagged NifH (yNifHmit) was purified from $S$. cerevisiae GF2 cells co-expressing mitochondrial NifM (yNifMmit) by anaerobic $\mathrm{Co}^{2+}$ affinity chromatography inside a glove box (Fig. 2a). A cytosolic version (lacking the mitochondrial leader sequence; Supplementary Fig. 1) of the his-tagged $\mathrm{NifH}$ (yNifHcyt) was also produced a

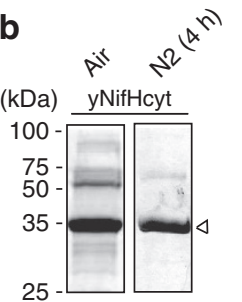

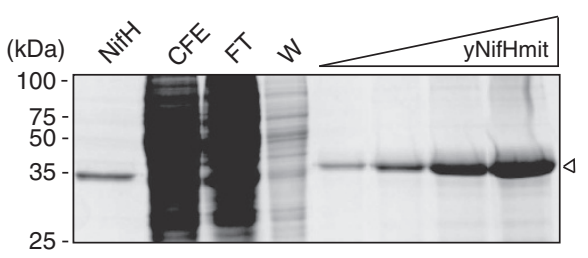

and purified from S. cerevisiae GF9 cells co-expressing yNifMcyt (Fig. 2b). In contrast to the colourless yNifHcyt, pure yNifHmit exhibited the characteristic brown colour of nitrogenase Fe protein.

yNifHmit was capable of acting as Fe protein in the donation of electrons to the MoFe protein purified from A. vinelandii cells, both in the reduction of acetylene to yield ethylene and in the reduction of $\mathrm{N}_{2}$ to yield $\mathrm{NH}_{3}$ (Table 1). The Fe protein activity of yNifHmit varied among preparations, and maximum activity of 1,600 units ( $\mathrm{nmol} \mathrm{C}_{2} \mathrm{H}_{4}$ formed · per minute - per milligram MoFe protein) was obtained at $\mathrm{Fe}$ protein to $\mathrm{MoFe}$ protein molar ratio of 200 (Supplementary Fig. 3). Importantly, under these conditions, yNifHmit was able to support the formation of as much as $800 \mathrm{nmol} \mathrm{NH}_{3}$. per minute - per milligram MoFe protein. Co-expression of $\mathrm{NifH}$ with $\mathrm{NifM}$ was required for Fe protein activity. When mitochondrially located $\mathrm{NifH}$ was expressed and purified from $S$. cerevisiae GF12 cells, which lack nif $M$, yNifHmit preparations were colourless and showed no Fe protein activity (Fig. $2 \mathrm{c}$ and Table 1). Fe protein activity of purified yNifHmit was independent of the aeration rate of the culture in the range of 0.1 to 1 litre air-per minute $\cdot$ per litre of culture.

In contrast, yNifHcyt exhibited no Fe protein activity, in agreement with previous data of expression of inactive NifH in S. cerevisiae ${ }^{26}$. To investigate whether $\mathrm{O}_{2}$ damage was inactivating yNifHcyt at the cytosol, aerated $S$. cerevisiae GF9 cultures expressing $\mathrm{NifH}$ were sparged with $\mathrm{N}_{2}$ during $4 \mathrm{~h}$ before collecting the cells. The yNifHcyt purified from $\mathrm{N}_{2}$-treated $S$. cerevisiae cultures (Fig. 2b) exhibited very low levels of $\mathrm{Fe}$ protein activity (Table 1) consistent with the in vivo repair of a small fraction of $\mathrm{NifH}$ metal clusters during the anoxic period. Altogether, these data show that mitochondrial targeting is necessary to obtain active $\mathrm{Fe}$ protein under aerobic growth conditions, probably by offering protection against $\mathrm{O}_{2}$ damage.

NifU and NifS requirement for Fe protein activity in yeast. Mitochondria carry the essential biosynthetic machinery for the assembly of $\mathrm{Fe}-\mathrm{S}$ clusters $^{21}$. Mitochondrial Isu1/Isu2 and Nfs1

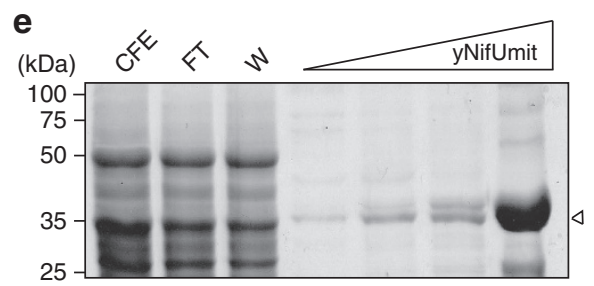

Figure 2 | Purification of $\mathbf{y N i f H}$ and $\mathbf{y N i f U}$ proteins. Aerated cultures (1 litre air - per minute - per litre of culture) of galactose-induced S. cerevisiae cells were used as source of Nif proteins. $\mathrm{Co}^{2+}$ or $\mathrm{Ni}^{2}+$ affinity columns were used for the purification of his-tagged $\mathrm{yNifH}$ and $\mathrm{yNifU}$, respectively. The migration of molecular weight markers in SDS-PAGE is indicated at the left side of each panel. Purified $A$. vinelandii $\mathrm{NifH}$ was added as control in a, c and d. CFE, cell-free extracts; FT, flow-through fractions; W, protein fractions eluted after washing with washing buffer; yNifHmit, yNifHcyt and yNifUmit indicate protein fractions eluted after applying imidazole to the affinity chromatography columns. Arrows point to purified $\mathrm{NifH}$ and $\mathrm{NifU}$ proteins. (a) yNifHmit purification from GF2 cells co-expressing mitochondria-targeted NifH and NifM. (b) yNifHcyt purified from aerated GF9 cells co-expressing cytosol-targeted NifH and NifM that were collected under aerobic conditions (air) or subjected to $4 \mathrm{~h}$ of intense $\mathrm{N}_{2}$ sparging before cell collection $\left(\mathrm{N}_{2}\right)$. (c) yNifHmit purification from GF12 cells, expressing mitochondria-targeted $\mathrm{NifH}$ in the absence of NifM.

(d) yNifHmit purification from GF11 cells co-expressing mitochondriatargeted tagged $\mathrm{NifH}$ and NifM along with non-tagged NifU and NifS. (e) yNifUmit purification from GF6 cells co-expressing mitochondriatargeted NifU and NifS.

\section{Table 1 | MoFe protein activity supported by yNifHmit and} yNifHcyt purified preparations.

\begin{tabular}{|c|c|c|c|c|}
\hline Fe protein & $\begin{array}{c}\text { Other } \\
\text { co-expressed } \\
\text { Nif proteins }\end{array}$ & $\begin{array}{c}\mathrm{C}_{2} \mathrm{H}_{2} \\
\text { reduction } \\
\text { activity }^{\star}\end{array}$ & $\begin{array}{c}\mathbf{N}_{\mathbf{2}} \\
\text { fixation } \\
\text { activity }\end{array}$ & $\begin{array}{c}\text { Fe protein to } \\
\text { MoFe protein } \\
\text { molar ratio }\end{array}$ \\
\hline \multicolumn{5}{|l|}{ Mitochondrial } \\
\hline yNifHmit & NifM & $404 \pm 62$ & ND & 20 \\
\hline yNifHmit & NifM & $1,600^{\ddagger}, \S$ & $826 \pm 60$ & 200 \\
\hline yNifHmit & None & $<0.01$ & ND & $\geq 400$ \\
\hline yNifHmitll & $\begin{array}{c}\text { NifM, NifU, } \\
\text { NifS }\end{array}$ & $430 \pm 45^{\S}$ & $511 \pm 10$ & 30 \\
\hline \multicolumn{5}{|l|}{ Cytosolic } \\
\hline yNifHcyt (air) & NifM & $<0.01$ & ND & $\geq 400$ \\
\hline yNifHcyt (air) & $\begin{array}{c}\text { NifM, NifU, } \\
\text { NifS }\end{array}$ & $<0.01$ & ND & $\geq 400$ \\
\hline yNifHcyt $\left(\mathrm{N}_{2}\right)$ & NifM & $102 \pm 2$ & ND & $\geq 400$ \\
\hline yNifHcyt $\left(\mathrm{N}_{2}\right)$ & $\begin{array}{c}\text { NifM, NifU, } \\
\text { NifS }\end{array}$ & $404 \pm 20$ & ND & 30 \\
\hline $\mathrm{NifH}^{\top}$ & & $1,652 \pm 23$ & $849 \pm 25$ & 40 \\
\hline \multicolumn{5}{|c|}{ 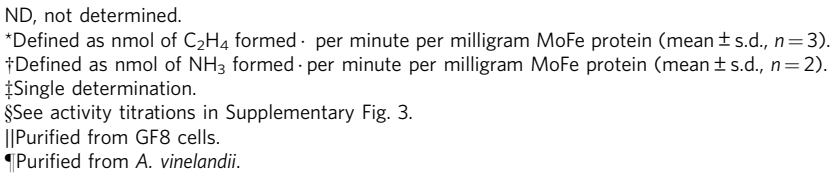 } \\
\hline
\end{tabular}


are homologues of bacterial housekeeping IscU and $\mathrm{IscS}^{27}$ proteins involved in general $\mathrm{Fe}-\mathrm{S}$ cluster assembly and the Nif-specific NifU and NifS. It was interesting to observe that, similar to the case in diazotrophic organisms ${ }^{27}$, NifU and NifS were not absolutely needed to produce active $\mathrm{Fe}$ protein in mitochondria. The fact that $y \mathrm{NifH}$ mit was purified in active form demonstrates the ability of the yeast machinery to load [4Fe-4S] clusters into apo-NifH.

In an attempt to enhance the $\mathrm{Fe}$ protein activity of yNifHmit, we generated a $S$. cerevisiae strain (GF8) expressing mitochondria-targeted and affinity-tagged NifH, NifM, NifU and NifS. yNifHmit was then purified from GF8 cell-free extracts, and $\mathrm{Fe}$ protein activity was determined after addition of pure A. vinelandii MoFe protein. Table 1 shows that co-expression of $\mathrm{NifH}$ and NifM with NifU and NifS did not improve mitochondrial $\mathrm{Fe}$ protein activity. In addition, $S$. cerevisiae GF11 strain expressing non-tagged NifU and NifS along with tagged $\mathrm{NifH}$ and NifM was generated to facilitate $\mathrm{yNifHmit}$ purification by preventing contamination with yNifUmit (Supplementary Fig. 4 and Fig. 2d), but no improvement in $\mathrm{Fe}$ protein activity over yNifHmit preparations from GF8 cells was observed.

Table 1 also shows that co-expression of cytosolic versions of NifU, NifS, NifH and NifM in GF13 cells subjected to $4 \mathrm{~h}$ of culture under anoxic conditions rendered similar levels of active Fe protein than the corresponding mitochondrial preparations from aerated GF8 cells. This result suggests that the failure to activate yNifHcyt under anoxic conditions in the absence of NifU and NifS (see above) was due to inability of the cytosolic CIA system to provide $[4 \mathrm{Fe}-4 \mathrm{~S}]$ clusters to apo-NifH. Importantly, aerobically grown GF13 cells rendered completely inactive Fe protein.

To determine whether mitochondria-targeted NifU was active in vitro, his-tagged $\mathrm{yNifUmit}$ was purified from S. cerevisiae GF6 strain carrying codon-optimized synthetic versions of the A. vinelandii nifU and nifS genes (Fig. 2e) and its properties compared with those of NifU purified from a recombinant E. coli strain carrying $A$. vinelandii nifU and nifS (EcNifU). Pure yNifUmit preparations were brown, contained two Fe atoms per dimer and exhibited ultraviolet-visible spectra characteristic of [2Fe-2S] proteins ${ }^{28}$, with $\varepsilon 420$ values consistent with the presence of a single [2Fe-2S] cluster per yNifUmit dimer (Fig. 3a). In contrast, EcNifU contained eight $\mathrm{Fe}$ atoms per dimer and its ultraviolet-visible spectrum was typical of [4Fe-4S] proteins. It is known that $A$. vinelandii NifU carries one permanent $[2 \mathrm{Fe}-2 \mathrm{~S}]$ cluster and one or two labile [4Fe-4S] clusters to be donated to target proteins, which are normally lost during purification ${ }^{29}$.

Activity of pure NifU preparations was tested by its ability to reconstitute $[\mathrm{Fe}-\mathrm{S}]$ clusters into $A$. vinelandii apo-NifH in reactions containing $\mathrm{Na}_{2} \mathrm{~S}$ as the source of sulfide and $\mathrm{Fe}\left(\mathrm{NH}_{4}\right)_{2}\left(\mathrm{SO}_{4}\right)_{2}$ as the source of ferrous iron. Both EcNifU and yNifUmit were able to reconstitute apo-NifH with high efficiency, generating similar amounts of active Fe protein (Fig. 3b). The substitution of cysteine and $A$. vinelandii NifS for $\mathrm{Na}_{2} \mathrm{~S}$ in the NifU-dependent apo-NifH reconstituting reactions also rendered active Fe protein (1,800 and 1,704 nmol ethylene $\cdot$ per minute $\cdot$ per milligram MoFe protein for yNifUmit and EcNifU reconstituted preparations, respectively), demonstrating the ability of EcNifU and yNifUmit to accept $\mathrm{S}$ atoms from NifS.

Pure yNifUmit was also used to investigate whether $S$. cerevisiae $\mathrm{NifH}$ preparations could be activated by $[\mathrm{Fe}-\mathrm{S}]$ cluster insertion in vitro (Fig. 3c). Surprisingly, while yNifHmit activity could be restored to levels as high as those of the A. vinelandii $\mathrm{NifH}$, yNifHcyt preparations were unable to accept $[\mathrm{Fe}-\mathrm{S}]$ clusters from yNifUmit, even in the presence of the thiol a
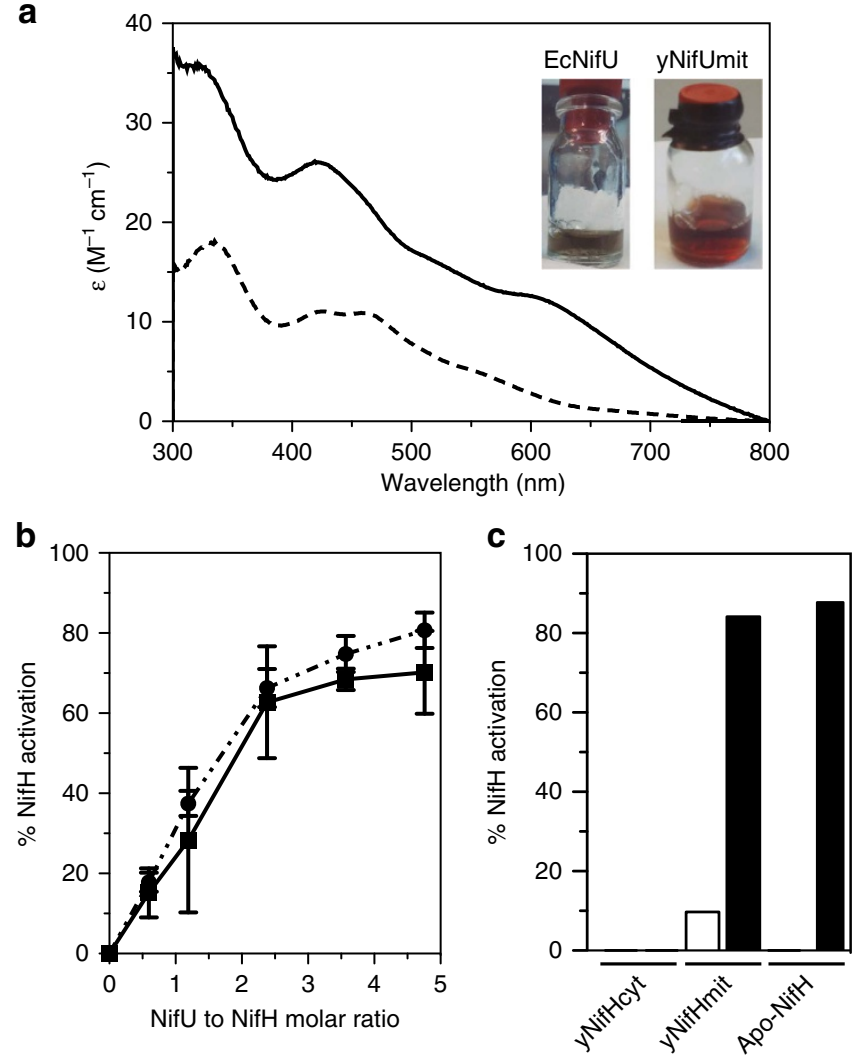

Figure 3 | Characterization of purified yNifUmit. (a) Purified preparations and ultraviolet-visible spectra of yNifUmit (190 $\mu \mathrm{M}$, broken line) and EcNifU (190 $\mu \mathrm{M}$, solid line). (b) Titration of apo-NifH activation by yNifUmit (broken line; $n=4$ ) or EcNifU (solid line; $n=2$ ). Data represent means \pm s.d. All assays contained $5 \mu \mathrm{M}$ apo-NifH $(162 \mu \mathrm{g})$ in the Fe-S cluster reconstitution phase. Fully active Fe protein supported MoFe protein specific activity of 2,200 nmol ethylene - per minute - per milligram MoFe protein (corresponding to $100 \%$ activity). (c) Activation assays of yNifHmit $(40 \mu \mathrm{g})$ and $\mathrm{yNifHcyt}(80 \mu \mathrm{g})$ with a 5 -fold molar excess of $y$ NifUmit. The yNifHmit and yNifHcyt proteins were purified from aerated cultures (1 litre air - per minute per litre of culture) of GF2 and GF9 strains, respectively. In vitro generated $\mathrm{A}$. vinelandii apo- $\mathrm{NifH}(80 \mu \mathrm{g})$ was used as control of activation reactions. MoFe protein-specific activity supported by fully active Fe protein under same assay conditions was 1,480 nmol ethylene · per minute per milligram MoFe protein (corresponding to $100 \%$ activity). Empty bar represents the Fe protein activity of purified yNifHmit before the yNifUmit-dependent activation assay. Non-activated A. vinelandii apo-NifH and yNifHcyt lacked Fe protein activity. yNifUmit was unable to endow yNifHcyt with Fe protein activity.

reductant $\beta$-mercaptoethanol, suggesting that the defect in yNifHcyt is more complex than lacking its [4Fe-4S] cluster. In addition, these results demonstrate that $\mathrm{yNifHmit}$ is produced in a mixture of active and NifU-activatable forms.

In conclusion, this work shows that yeast mitochondria are capable of accumulating active NifU and Fe protein despite their extreme $\mathrm{O}_{2}$ sensitivity. The $\mathrm{Fe}$ protein is particularly relevant because it is one of the two structural components of nitrogenase. It is also noteworthy that endogenous mitochondrial $\mathrm{Fe}-\mathrm{S}$ cluster assembly machinery is able to provide NifU and $\mathrm{NifH}$ with metal clusters, at least to some extent. By breaking through the limitation imposed by $\mathrm{O}_{2}$ in the production of an active nitrogenase within a eukaryotic cell, this work provides enabling technology that is instrumental for the grand challenge of engineering $\mathrm{N}_{2}$-fixing cereals. 


\section{Methods}

Expression of Nif proteins in S. cerevisiae. Inoculating cultures were prepared by growing $S$. cerevisiae at $30^{\circ} \mathrm{C}$ and 200 r.p.m. in 1-litre flasks containing $500 \mathrm{ml}$ of SD medium supplemented with auxotrophic requirements to an $D_{600}$ of 0.6 . For protein purification experiments, $S$. cerevisiae cells were cultivated in 20 -litre batches of SD medium supplemented with $0.5 \%$ of yeast extract, $2.5 \%$ of bactopeptone and $100 \mu \mathrm{M}$ of ammonium iron (III) citrate, in a 250-litre fermentor (Bioprocess Technology, Spain) until glucose was consumed at which time $2 \%$ galactose and $8 \mathrm{ml}$ of a trace element solution $\left(13 \mathrm{gl}^{-1} \mathrm{CaCl}_{2}\right.$, $2.5 \mathrm{gl}^{-1} \mathrm{MnCl}_{2}, 0.5 \mathrm{gl}^{-1} \mathrm{ZnSO}_{4}, 1.4 \mathrm{gl}^{-1} \mathrm{Na}_{2} \mathrm{MoO}_{4}, 1.85 \mathrm{gl}^{-1} \mathrm{FeCl}_{3}, 1 \mathrm{gl}^{-1}$ $\mathrm{H}_{3} \mathrm{BO}_{4}, 0.7 \mathrm{gl}^{-1} \mathrm{IK}$ in $2 \mathrm{M} \mathrm{HCl}$ ) was added to induce nif gene expression. Dissolved $\mathrm{O}_{2}$ was monitored continuously during the fermentation processes by using a Mettler Toledo InPro 6850 sensor immersed into the culture. The cells were collected under anaerobic conditions $20 \mathrm{~h}$ after galactose addition by using hollow fiber filtration followed by centrifugation at $4{ }^{\circ} \mathrm{C}$ and 4,000 r.c.f. for $5 \mathrm{~min}$. The recovered cell paste was frozen and stored into liquid $\mathrm{N}_{2}$ until used.

yNifH purification. S. cerevisiae cells (strains GF2, GF8, GF9, GF11, GF12 and GF13) were resuspended in anaerobic lysis buffer containing $100 \mathrm{mM}$ Tris- $\mathrm{HCl}$ $\mathrm{pH} 8.0,100 \mathrm{mM} \mathrm{NaCl}, 1 \mathrm{mM}$ phenylmethylsulfonyl fluoride (PMSF), $1 \mu \mathrm{g} \mathrm{ml}^{-1}$ leupeptin, $2 \mathrm{mM}$ sodium dithionite (DTH), $5 \mu \mathrm{g} \mathrm{ml}^{-1}$ DNaseI, and $1 \mathrm{mgg}^{-1}$ cell of Zymolyase-20T (Nacalai Tesque). The cells were lysed in a French Press cell at $25,000 \mathrm{lb}$ per square inch. Cell-free extracts were obtained after removing cell debris by centrifugation at $73,000 \mathrm{~g}$ for $1 \mathrm{~h}$ at $4{ }^{\circ} \mathrm{C}$ under anaerobic conditions. The yNifH protein was purified by $\mathrm{Co}^{2+}$ affinity chromatography under anaerobic conditions (<0.1 p.p.m. $\mathrm{O}_{2}$ ) using an AKTA Prime FPLC system (GE Healthcare) inside a glovebox (MBraun). In a typical purification, cell-free extract from $150 \mathrm{~g}$ of cell paste was loaded at $2 \mathrm{ml} \mathrm{min}{ }^{-1}$ onto a column filled with $20 \mathrm{ml}$ TALON resin (Clontech) equilibrated with lysis buffer, washed with 10 column volumes of washing buffer (100 mM Tris- $\mathrm{HCl} \mathrm{pH} 8.0,250 \mathrm{mM} \mathrm{NaCl})$ and eluted with four column volumes of elution buffer $(100 \mathrm{mM}$ Tris- $\mathrm{HCl}$ pH $8.0,250 \mathrm{mM} \mathrm{NaCl}$, $250 \mathrm{mM}$ imidazole). Elution fractions were concentrated using a Vivaspin 500 concentrator (Sartorius) with cutoff pore size of $30 \mathrm{kDa}$, and then desalted in PD10 or HiPrep 26/10 columns (GE Healthcare) equilibrated with $50 \mathrm{mM}$ Tris-HCl $\mathrm{pH} 8$, and $300 \mathrm{mM} \mathrm{NaCl}$. Purified yNifHmit or yNifHcyt preparations were frozen as droplets in liquid $\mathrm{N}_{2}$. When purifying from GF8 cells, yNifHmit preparations contained large amounts of yNifUmit.

yNifU purification. S. cerevisiae GF6 cells were resuspended in anaerobic Buffer B (100 mM Tris-HCl pH 7.9, $500 \mathrm{mM} \mathrm{NaCl}, 10 \%$ glycerol, $10 \mathrm{mM} \mathrm{MgCl}_{2}$ ) supplemented with $0.2 \mathrm{mM}$ PMSF, $1 \mu \mathrm{g} \mathrm{ml}^{-1}$ leupeptin, $5 \mu \mathrm{g} \mathrm{ml}^{-1} \mathrm{DNaseI}$, and $0.5 \mathrm{mg} \mathrm{g}^{-1}$ cell of Zymolyase-20 T. The cells were lysed in an Emulsiflex-C5 homogenizer (Avestin Inc.) at $25,000 \mathrm{lb}$ per square inch. The cell-free extracts were obtained after removing debris by centrifugation at $100,000 \mathrm{~g}$ for $1 \mathrm{~h}$ at $4{ }^{\circ} \mathrm{C}$ under anaerobic conditions. The cell-free extracts were supplemented with $0.5 \mathrm{mM}$ of L-cysteine, $2 \mathrm{mM}$ of $\mathrm{Fe}\left(\mathrm{NH}_{4}\right)_{2}\left(\mathrm{SO}_{4}\right)_{2}$ and $2 \mathrm{mM}$ of $\beta$-mercaptoethanol, and incubated for $1 \mathrm{~h}$ at room temperature. The yNifU protein was purified by $\mathrm{Ni}^{2}+$ affinity chromatography under anaerobic conditions $\left(<0.1\right.$ p.p.m. $\left.\mathrm{O}_{2}\right)$ using an AKTA Prime FPLC system (GE Healthcare) inside a glovebox (MBraun). In a typical purification, the cell-free extract from $200 \mathrm{~g}$ of cell paste was loaded at $2 \mathrm{ml} \mathrm{min}^{-}$ onto a column filled with $5 \mathrm{ml}$ IMAC resin (GE Healthcare) equilibrated with Buffer B and washed with three successive washes of Buffer B supplemented with $15 \mathrm{mM}$ imidazole, $30 \mathrm{mM}$, and $45 \mathrm{mM}$ imidazole, respectively. Bound protein was eluted with elution buffer containing $50 \mathrm{mM}$ Tris- $\mathrm{HCl} \mathrm{pH} 7.9,150 \mathrm{mM} \mathrm{NaCl}, 10 \%$ glycerol and $250 \mathrm{mM}$ imidazole. The eluted fractions were concentrated using a $30-\mathrm{kDa}$ cutoff pore Centricon 500 (Millipore) and then desalted in PD10 columns

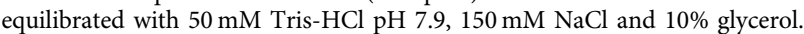
Purified yNifU preparations were frozen as droplets in liquid $\mathrm{N}_{2}$.

Fe protein activity determination. Fe protein activity of yNifH preparations purified from $S$. cerevisiae cells was routinely analysed by the acetylene reduction assay after addition of excess MoFe protein and ATP-regenerating mixture (1.23 mM ATP, $18 \mathrm{mM}$ phosphocreatine, $2.2 \mathrm{mM} \mathrm{MgCl}_{2}, 3 \mathrm{mM}$ DTH and $40 \mu \mathrm{g}$ of creatine phosphokinase $)^{10}$. Positive control reactions were carried out with pure preparations of $A$. vinelandii $\mathrm{Fe}$ protein and MoFe protein ${ }^{8}$. To determine $\mathrm{NH}_{3}$-producing activity of $\mathrm{MoFe}$ protein with yNifH, argon gas was evacuated from reaction vials and replaced by $\mathrm{N}_{2}$ at $1 \mathrm{~atm}$. The reactions were carried out at $30{ }^{\circ} \mathrm{C}$ for $60 \mathrm{~min}$ and then stopped by the addition of $50 \mathrm{mM}$ EDTA. The $\mathrm{NH}_{3}$ produced was determined by liquid chromatographic fluorescence according to ref. 30 with modifications. Two hundred microlitres of each reaction mixture were withdrawn, mixed with $1 \mathrm{ml}$ of fluoraldehyde and incubated in the dark for $60 \mathrm{~min}$. Five hundred microlitres of these mixtures were subjected to HPLC separation (Agilent 1200 HPLC), and the ammonia-containing fractions were collected in multiwell black plates and their fluorescence quantified with a Tecan/ GENios Pro fluorescence detector.

In vitro apo-NifH reconstitution assays. Apo-NifH from $A$. vinelandii was prepared in vitro according to ref. 31. The presence of apo- $\mathrm{NifH}$ in pure yNifH preparations was determined by the in vitro reconstitution of its $[4 \mathrm{Fe}-4 \mathrm{~S}]$ cluster according to ref. 20 with the following modifications. Each [4Fe-4S] cluster assembly mixture included $25 \mathrm{mM}$ Tris- $\mathrm{HCl}$ pH 7.4, $3 \mathrm{mM} \beta$-mercaptoethanol, $50 \mu \mathrm{M}$ NifU (either yNifU or EcNifU), $1 \mathrm{mM} \mathrm{Fe}\left(\mathrm{NH}_{4}\right)_{2}\left(\mathrm{SO}_{4}\right)_{2}$ and either $0.5 \mathrm{mM}$ of $\mathrm{Na}_{2} \mathrm{~S}$ or $20 \mu \mathrm{M}$ EcNifS plus $0.5 \mathrm{mM}$ L-cysteine. The reaction mixtures were incubated for $3 \mathrm{~h}$ at $12^{\circ} \mathrm{C}$ to allow the formation of $[\mathrm{Fe}-\mathrm{S}]$ clusters onto NifU. Assays lacking NifU were carried out as control reactions. Apo-NifH or yNifH samples were then added to the $[4 \mathrm{Fe}-4 \mathrm{~S}]$ cluster assembly reaction mixture. In $\mathrm{NifU}$ titration experiments, $162 \mu \mathrm{g}$ apo-NifH were assayed in combination with different volumes of the $[4 \mathrm{Fe}-4 \mathrm{~S}]$ cluster assembly reaction to obtain NifU/NifH molar ratios of $0.6,1.2,1.8,2.4,3.6$ and 4.8 . To establish the $100 \%$ Fe protein activity level under the same reaction conditions, control reactions lacking apo-NifH and containing $162 \mu \mathrm{g}$ NifH were carried out. In yNifHmit and yNifHcyt reconstitution assays, $40-80 \mu \mathrm{g}$ y NifH and a NifU to $\mathrm{NifH}$ molar ratio of 5 were used. In all the cases, acetylene reduction assays were conducted immediately after addition of apo-NifH to the [4Fe-4S] cluster assembly reactions by adding 30-60 $\mu \mathrm{g}$ of pure MoFe protein, $600 \mu \mathrm{l}$ of an ATP mix and 7\% acetylene, followed by incubation during $15 \mathrm{~min}$ at $30^{\circ} \mathrm{C}$ in a rotary shaker. The reactions were stopped by adding $0.1 \mathrm{ml}$ of $8 \mathrm{~N} \mathrm{NaOH}$ and the ethylene formed were measured with a Shimadzu model GC2014 gas chromatograph equipped with a Porapak $\mathrm{N}^{10}$

Aconitase activity and protein methods. Aconitase activity was determined in cell-free extracts according to ref. 32. Reaction mixtures containing $0.1 \mathrm{ml}$ of S. cerevisiae GF2 cell-free extract, $0.9 \mathrm{ml}$ of anaerobic lysis buffer were incubated at room temperature. Formation of cis-aconitate was measured after the addition of $2 \mathrm{mM}$ DL-isocitrate by following the increase in absorbance at $240 \mathrm{~nm}$. Protein concentration was determined by bicinchoninic acid method (Pierce), with bovine serum albumin as the standard ${ }^{33}$. Colorimetric Fe determination was performed by the $\alpha, \alpha^{\prime}$ bipyridyl method ${ }^{34}$. Protein samples $(0.2 \mathrm{ml})$ were incubated with $0.1 \mathrm{ml}$ of $\mathrm{HCl} 0.1 \mathrm{~N}$ for $60 \mathrm{~min}$ at $100{ }^{\circ} \mathrm{C}$, cooled down to room temperature, mixed with $0.7 \mathrm{ml}$ of a solution containing $200 \mathrm{mM}$ hydroxylamine and $1.72 \mathrm{mM} \alpha, \alpha^{\prime}$ bipyridyl, and incubated for $30 \mathrm{~min}$ at room temperature. The resulting absorbance at $520 \mathrm{~nm}$ was determined in a ultraviolet-visible spectrophotometer and referenced to calibration curves obtained with known amounts of Fe. SDS-PAGE was performed by standard methods. Immunoblot analyses were carried out with antibodies raised against the $A$. vinelandii $\mathrm{NifH}$ (1:5,000 dilution), NifU (1:3,000 dilution), and NifS (1:250 dilution) proteins, the Flag tag (1:2,500 dilution, Sigma Aldrich catalogue \#F7425) or the S. cerevisiae Yah1 protein (1:500 dilution; antibody kindly donated by Rolland Lill, Marburg University). Secondary antirabbit antibodies were used at 1:10,000 dilution (Sigma Aldrich catalogue \#A3687). Full immunoblot scans are shown in Supplementary Fig. 5.

Confocal fluorescence microscopy. S. cerevisiae GF3, GF4, GF5 and GF7 strains were grown at $30^{\circ} \mathrm{C}$ in 1-litre flasks containing $500 \mathrm{ml}$ of SD medium supplemented with auxotrophic requirements to an $D_{600}$ of 0.6 . The cells were then collected by centrifugation, washed with SD medium lacking glucose, resuspended in SD medium supplemented with $2 \%$ galactose to induce $\mathrm{NifH}$ and NifM expression, and incubated under the same conditions for $24 \mathrm{~h}$. The induced cells were collected at $4{ }^{\circ} \mathrm{C}$ by centrifugation at 4,500 r.c.f. for $5 \mathrm{~min}$ and then resuspended in yeast suspension buffer containing $50 \mathrm{mM}$ Tris- $\mathrm{HCl} \mathrm{pH} \mathrm{7.5,5 \textrm {mM }}$ EDTA, $10 \%$ glycerol and $1 \mathrm{mM}$ PMSF. Whole-cell fluorescence was analysed by using a confocal microscope Leica TCS SP8 equipped with a PL APO $40 \times / 1,1$ water immersion objective. Excitation beam splitters TD 488/561/633 were used to capture detailed localization images of yEGFP-NifH, NifM-mKO, yEGFP-NifS and NifU-mKO fusion proteins. In parallel, galactose-induced cells were treated with $200 \mathrm{nM}$ MitoTracker Deep Red (Invitrogen) to stain for mitochondria according to the manufacturer's instructions.

Isolation and analysis of mitochondrial preparations. S. cerevisiae GF8 strain was grown at $30^{\circ} \mathrm{C}$ in 2-litre flasks containing 1 litre of SD medium supplemented with auxotrophic requirements to an $D_{600}$ of 0.6 . The cells were then collected by centrifugation, washed with SD medium lacking glucose, resuspended in SD medium supplemented with $2 \%$ galactose to induce NifH, NifM, NifU and NifS expression, and incubated under the same conditions for $24 \mathrm{~h}$. The procedure for mitochondria isolation has been described ${ }^{35}$. Ten grams of galactose-induced $S$. cerevisiae cells were collected at $4^{\circ} \mathrm{C}$ by centrifugation at 3,000 r.c.f. for $5 \mathrm{~min}$, resuspended in $40 \mathrm{ml}$ of SP buffer (1.2 M sorbitol, $20 \mathrm{mM}$ potassium phosphate $\mathrm{pH} 7.4$ ) and incubated with Zymolyase-20 $\mathrm{T}$ ( $2 \mathrm{mgg}^{-1}$ cells) during $30 \mathrm{~min}$ at $30^{\circ} \mathrm{C}$ under gentle shaking to obtain spheroplasts. All subsequent operations were conducted at $0{ }^{\circ} \mathrm{C}$. The spheroplasts were collected by centrifugation at 800 r.c.f. for $5 \mathrm{~min}$, washed and resuspended in SHP buffer (1.2 M sorbitol, $40 \mathrm{mM}$ HEPES $\mathrm{KOH}, \mathrm{pH} 7.4,1 \mathrm{mM}$ PMSF) and homogenized in a 50-ml glass homogenizer. The cell debris was removed by centrifuging twice at 800 r.c.f. for $5 \mathrm{~min}$. The mitochondria in the supernatant fraction were pelleted by centrifugation at 17,000 r.c.f. for $10 \mathrm{~min}$, resuspended in $20 \mathrm{ml}$ of SH buffer $(0.6 \mathrm{M}$ sorbitol, $20 \mathrm{mM}$ HEPES-KOH, $\mathrm{pH} 7.4$ ), subjected again to differential centrifugation at 800 and 17,000 r.c.f. and finally resuspended in $0.5 \mathrm{ml}$ of SH buffer. Mitochondrial preparations were stored at $-80^{\circ} \mathrm{C}$ until used. The assay for integrity of mitochondria involves their treatment with proteinase $\mathrm{K}\left(5 \mathrm{ng} \mathrm{\mu l}^{-1}\right.$ mitochondria) in the absence or presence of $2 \mathrm{mM} \mathrm{CaCl}_{2}$ and $1 \%$ Triton $\mathrm{X}-100$ for $30 \mathrm{~min}$ at $30^{\circ} \mathrm{C}$ 
and the analysis of the degree of proteolytic protection by SDS-PAGE and immunoblot. The Yah1 ferredoxin, is used as reference of protein present in the mitochondrial matrix.

\section{References}

1. Mueller, N. D. et al. Closing yield gaps through nutrient and water management. Nature 490, 254-257 (2012).

2. Erisman, J. W., Sutton, M. A., Galloway, J., Klimont, Z. \& Winiwarter, W. How a century of ammonia synthesis changed the world. Nat. Geosci. 1, 636-639 (2008).

3. Foley, J. A. et al. Solutions for a cultivated planet. Nature 478, 337-342 (2011).

4. Beatty, P. H. \& Good, A. G. Plant science. Future prospects for cereals that fix nitrogen. Science 333, 416-417 (2011).

5. Curatti, L. \& Rubio, L. M. Challenges to develop nitrogen-fixing cereals by direct nif-gene transfer. Plant Sci. 225, 130-137 (2014).

6. Oldroyd, G. E. D. \& Dixon, R. A. Biotechnological solutions to the nitrogen problem. Curr. Opin. Biotechnol. 26, 19-24 (2014)

7. Hoffman, B. M., Lukoyanov, D., Yang, Z. Y., Dean, D. R. \& Seefeldt, L. C. Mechanism of nitrogen fixation by nitrogenase: the next stage. Chem. Rev. 114, 4041-4062 (2014).

8. Curatti, L. et al. In vitro synthesis of the iron-molybdenum cofactor of nitrogenase from iron, sulfur, molybdenum, and homocitrate using purified proteins. Proc. Natl Acad. Sci. USA 104, 17626-17631 (2007).

9. Rubio, L. M. \& Ludden, P. W. Biosynthesis of the iron-molybdenum cofactor of nitrogenase. Annu. Rev. Microbiol. 62, 93-111 (2008).

10. Shah, V. K. \& Brill, W. J. Nitrogenase. IV. Simple method of purification to homogeneity of nitrogenase components from Azotobacter vinelandii. Biochim. Biophys. Acta 305, 445-454 (1973).

11. Curatti, L., Ludden, P. W. \& Rubio, L. M. NifB-dependent in vitro synthesis of the iron-molybdenum cofactor of nitrogenase. Proc. Natl Acad. Sci. USA 103, 5297-5301 (2006).

12. Goodwin, P. J. et al. The Azotobacter vinelandii NifEN complex contains two identical [4Fe-4S] clusters. Biochemistry 37, 10420-10428 (1998).

13. Poole, R. K. \& Hill, S. Respiratory protection of nitrogenase activity in Azotobacter vinelandii: roles of the terminal oxidases. Biosci. Rep. 17, 303-317 (1997).

14. Eady, R. R., Smith, B. E., Cook, K. A. \& Postgate, J. R. Nitrogenase of Klebsiella pneumoniae. Purification and properties of the component proteins. Biochem. J. 128, 655-675 (1972).

15. Jacobson, M. R. et al. Biochemical and genetic analysis of the nifUSVWZM cluster from Azotobacter vinelandii. Mol. Gen. Genet. 219, 49-57 (1989).

16. Roberts, G. P., MacNeil, T., MacNeil, D. \& Brill, W. J. Regulation and characterization of protein products coded by the nif (nitrogen fixation) genes of Klebsiella pneumoniae. J. Bacteriol. 136, 267-279 (1978).

17. Gavini, N., Tungtur, S. \& Pulakat, L. Peptidyl-prolyl cis/trans isomeraseindependent functional NifH mutant of Azotobacter vinelandii. J. Bacteriol. 188, 6020-6025 (2006).

18. Zheng, L., White, R. H., Cash, V. L., Jack, R. F. \& Dean, D. R. Cysteine desulfurase activity indicates a role for NIFS in metallocluster biosynthesis. Proc. Natl Acad. Sci. USA 90, 2754-2758 (1993).

19. Yuvaniyama, P., Agar, J. N., Cash, V. L., Johnson, M. K. \& Dean, D. R. NifS-directed assembly of a transient [2Fe-2S] cluster within the NifU protein. Proc. Natl Acad. Sci. USA 97, 599-604 (2000).

20. Dos Santos, P. C. et al. Iron-sulfur cluster assembly: NifU-directed activation of the nitrogenase Fe protein. J. Biol. Chem. 279, 19705-19711 (2004).

21. Lill, R. Function and biogenesis of iron-sulphur proteins. Nature 460, 831-838 (2009).

22. de la Loza, M. C. \& Wellinger, R. E. A novel approach for organelle-specific DNA damage targeting reveals different susceptibility of mitochondrial DNA to the anticancer drugs camptothecin and topotecan. Nucleic Acids Res. 37, e26 (2009).

23. Westermann, B. \& Neupert, W. Mitochondria-targeted green fluorescent proteins: convenient tools for the study of organelle biogenesis in Saccharomyces cerevisiae. Yeast 16, 1421-1427 (2000).

24. Gardner, P. R., Nguyen, D. D. \& White, C. W. Aconitase is a sensitive and critical target of oxygen poisoning in cultured mammalian cells and in rat lungs. Proc. Natl Acad. Sci. USA 91, 12248-12252 (1994).
25. Curatti, L., Brown, C. S., Ludden, P. W. \& Rubio, L. M. Genes required for rapid expression of nitrogenase activity in Azotobacter vinelandii. Proc. Natl Acad. Sci. USA 102, 6291-6296 (2005).

26. Berman, J., Gershoni, J. M. \& Zamir, A. Expression of nitrogen fixation genes in foreign hosts. Assembly of nitrogenase Fe protein in Escherichia coli and in yeast. J. Biol. Chem. 260, 5240-5243 (1985).

27. Zheng, L., Cash, V. L., Flint, D. H. \& Dean, D. R. Assembly of iron-sulfur clusters. Identification of an iscSUA-hscBA-fdx gene cluster from Azotobacter vinelandii. J. Biol. Chem. 273, 13264-13272 (1998).

28. Gao, H. et al. Arabidopsis thaliana Nfu2 accommodates [2Fe-2S] or [4Fe-4S] clusters and is competent for in vitro maturation of chloroplast $[2 \mathrm{Fe}-2 \mathrm{~S}]$ and [4Fe-4S] cluster-containing proteins. Biochemistry 52, 6633-6645 (2013).

29. Smith, A. D. et al. NifS-mediated assembly of [4Fe-4S] clusters in the N-and C-terminal domains of the NifU scaffold protein. Biochemistry 44, 12955-12969 (2005).

30. Corbin, J. Liquid chromatograpic-fluorescence determination of ammonia from nitrogenase reactions: a 2-min assay. Appl. Environ. Microbiol. 1984, 1027-1030 (1984).

31. Rangaraj, P., Shah, V. K. \& Ludden, P. W. ApoNifH functions in ironmolybdenum cofactor synthesis and apodinitrogenase maturation. Proc. Natl Acad. Sci. USA 94, 11250-11255 (1997).

32. Kennedy, M. C., Emptage, M. H., Dreyer, J. L. \& Beinert, H. The role of iron in the activation-inactivation of aconitase. J. Biol. Chem. 258, 11098-11105 (1983).

33. Smith, P. K. et al. Measurement of protein using bicinchoninic acid. Anal. Biochem. 150, 76-85 (1985).

34. Moss, M. L. \& Mellon, M. G. Colorimetric determination of iron with 2,2'-bipyridyl and with 2,2',2"- terpyridyl. Ind. Eng. Chem. Anal. Ed. 14, 862-865 (1942).

35. Diekert, K., de Kroon, A. I., Kispal, G. \& Lill, R. Isolation and subfractionation of mitochondria from the yeast Saccharomyces cerevisiae. Methods Cell Biol. 65 , 37-51 (2001).

\section{Acknowledgements}

This work was supported by Bill \& Melinda Gates Foundation Grant OPP1042444 to L.M.R. We thank Elena Caro, Stefan Buren and Ryan Kniewel for helpful discussions. We thank Roland Lill for providing Yahl antibody.

\section{Author contributions}

G.L.-T. carried out molecular biology, cellular biology, confocal microscopy, protein purification and biochemical studies. E.J.-V. and J.A.H. purified A. vinelandii Nif proteins and carried out biochemical studies. J.M.B. carried out fermentations. H.K.V. carried out molecular biology studies. G.L.-T., E.J.-V., J.M.B., J.A.H. and L.M.R contributed to the experimental design and data analysis. G.L.-T and L.M.R. wrote the paper. L.M.R initiated and directed this research.

\section{Additional information}

Supplementary Information accompanies this paper at http://www.nature.com/ naturecommunications

Competing financial interests: Universidad Politécnica de Madrid has a patent application (EP2848684) on parts of this work of which G.L.-T., E.J.-V., J.M.B. and L.M.R. are inventors.

Reprints and permission information is available online at http://npg.nature.com/ reprintsandpermissions/

How to cite this article: López-Torrejón, G. et al. Expression of a functional oxygen-labile nitrogenase component in the mitochondrial matrix of aerobically grown yeast. Nat. Commun. 7:11426 doi: 10.1038/ncomms11426 (2016).

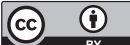

This work is licensed under a Creative Commons Attribution 4.0 International License. The images or other third party material in this article are included in the article's Creative Commons license, unless indicated otherwise in the credit line; if the material is not included under the Creative Commons license, users will need to obtain permission from the license holder to reproduce the material. To view a copy of this license, visit http://creativecommons.org/licenses/by/4.0/
} 